\title{
The Impact of Single Windows on Trade
}

\author{
The World Economy (2020), forthcoming
}

\author{
Inmaculada Martínez-Zarzoso** \\ University of Göttingen and Universitat Jaume I \\ Santiago Chelala* \\ University of Buenos Aires and Universidad \\ Argentina de la Empresa (UADE)
}

\begin{abstract}
This article is the first that quantifies the impact of single windows (SWs) on international trade globally. SWs function as a single point of entry and exit of the goods traded internationally and are therefore intended to facilitate trade. Using a structural gravity model for a panel of 176 countries from 1995 to 2017, we apply a log-log and a Poisson pseudo-maximum likelihood estimator (PPML) will multi-dimensional fixed effects to evaluate the extent to which export and import flows vary depending on whether or not countries have operational SWs. The main results from the linearized gravity model suggest that total trade between two countries with functioning SWs increases by about 37 percent, of which 23 corresponds to exports and 14 to imports. The result from the PPML estimation also indicate a positive and significant effect, which is however much smaller in magnitude.
\end{abstract}

Key words: International trade, single window, technology

JEL code: F13; O33.

\footnotetext{
F** Financial support received from the Spanish Ministry of Economy and Competitiveness, Project ECO2017-83255-C3-3-P (AEI, FEDER, EU) and from project UJI-B2017-33 is gratefully acknowledged.

* The authors wish to say a special thank you to Christian Volpe Martincus for having shared a database on the current status of SWs in different parts of the world, and to Bianca Pacini for her help in finding further information on these. We also thank Ady Beitler and Nadia Hewett for the invitation to participate in a WEF workshop on SW and blockchain.
} 


\section{Introduction}

Many countries have implemented or are in the process of implementing single windows for foreign trade (SWs), which function as a single point of entry where all the regulatory documentation needed to export or import goods converges.

Although there is consensus on the advantages of the system, few studies have analyzed the impact it has on import and export performance and the existing analysis are mostly for single countries (Volpe Martincus, 2017). Quantitative estimates are generally measured in terms of the number of days saved on the paperwork or formalities involved in foreign trade or the actual numbers of documents needed to complete these operations (Linke, 2012).

This article provides an alternative impact assessment by estimating how SWs impact a country's export performance. To this end, we estimate a structural gravity model for a sample of 176 countries over the period from 1995 to 2017 for the flow of bilateral exports from (imports to) countries with or without functioning SWs. More specifically, we examine the impact of SWs on trade by estimating how much trade increases when these trade facilitation instruments are implemented. With this aim, we employ a two-steps approach (Head and Mayer, 2014): In the first step a PPML estimator with multi-dimensional fixed effects is estimated, from which the country-time fixed effects are recovered, whereas in the second step those are used as dependent variables and regressed on the SW indicator.

The main results obtained from the estimations of the log-log gravity model estimated with multidimensional fixed effects show that total trade between two countries with functioning SWs increases by about 37\%, of which 23 corresponds to exports and 14 to imports. However, the results are more modest when the PPML estimation of the gravity model is considered.

The article is organized as follows: The second section describes the history of SWs, the third section summarizes the related literature, the fourth section presents the empirical methodology for measuring the impact of SWs on trade and sets out the main results, and the fifth section contains our conclusions. 


\section{A Brief History of Single Windows}

Improving the efficiency of cross-border trade is a pressing need for both developing and developed countries. Although there are earlier examples of SW-like mechanisms based on more rudimentary information technology, SWs really began to take off at the end of the 20th century with the spread of the internet.

The work of the United Nations Economic Commission for Europe was key to this process: in 2003, it recommended establishing SWs to simplify border formalities by unifying paperwork into a single electronic record that would comply with regulatory requirements and facilitate the work of border agencies and the business community (UNECE, 2003).

UNECE (2003) defines SWs as an environment that enables and streamlines flows of information between those involved in cross-border trade and government entities, bringing significant gains to all parties. These "one-stop shops" allow agents to submit all information needed for complying with the regulatory requirements for importing or exporting through a single channel. SWs also store standardized information and documents and function as a single entry point, such that the specific information for complying with export, import, and transit requirements only needs to be uploaded into the system once.

In general exporters or importers must fill in the electronic forms in their own country for export or import using SWs. ${ }^{1}$ Single window projects usually involve IT-based innovation, but also create a platform for effective collaboration at the border between Customs, Other Government Agencies (OGAs) and businesses. SW could be viewed as a concept embracing a set of precepts and building

\footnotetext{
${ }^{1}$ Data could be submitted from various entities depending on the country. Goods data is sent by the importer, exporter or agent (broker). In some cases, all declaring agents (party legally responsible for the cargo) that are registered with the Custom can submit the data (Economic Commission for Europe:UN/CEFAT, 2019).
} 
blocks designed to allow government to enhance its ability to administer and enforce legal requirements across multiple agencies via the use of integrated processes, while at the same time enabling the rapid and efficient flow of legitimate trade across the border (Widdowson et all, 2019). Several developed and developing countries began to pay heed to this recommendation, which was followed by a series of specific studies to help countries implement their own SWs. UN/CEFACT (2005) (or Recommendation 33, as it is commonly known) sets out a number of necessary factors for successful implementation. The list of requirements includes political will, strong leadership from the lead government agency, a strategic partnership between the government and key stakeholders in foreign trade, and appropriate communication and marketing policy.

Recommendation 33 was followed by Recommendation 34 on the simplification and standardization of data for trade and Recommendation 35 on the legal framework for SWs. The latter sought to create a solid legal regime which allows for data to be collected, accessed, and distributed and "clarifies confidentiality, privacy and liability regimes, [making] it possible to create a solid basis for the operation of the facility, and build a relationship of trust between all stakeholders."

Recommendation 36 concerns the interoperability of SWs (UN/CEFACT, 2017), where the term "interoperability" is defined as the ability of two or more systems or components to exchange information and use that information across borders with no additional effort on the part of the trader. The objective of making SWs interoperable is to promote the digital exchange of information between government agencies from different countries and thus to streamline cross-border trade. ${ }^{2}$

The consensus around the benefits of one-stop shops or SWs has grown over time. In 2012, the European Parliament established that one of the ultimate objectives of the European Union's trade policy is to implement a system that will enable member countries to process all exports and imports and check regulatory requirements through a single interface. However, it also warned that the system

\footnotetext{
${ }^{2}$ Bernal Turnes (2015) describes ISWs as windows that are potentially interoperable and provides guidelines on the mechanisms and systems required to interconnect two or more national SWs, be they public or private.
} 
needs to be flexible and sufficiently adaptable to include other agencies and authorities in addition to customs.

The difficulties this entails have also become evident. The World Bank (2014) warns that implementing such systems can take many years and should be carried out in several stages. It requires long-term commitment from both the public- and private-sphere stakeholders involved. The European Commission (2015) described the difficulties around getting EU member countries to make headway on this initiative and implement an SW system. As mentioned, governments have focused on creating national SW systems without acting in a coordinated fashion to facilitate the interoperability of SWs. For example, to move toward interoperability, it would be helpful if trade agreements between countries included detailed clauses for information exchange.

More recently, WEF (2018) called for a governance model for interoperability to be defined and for the relevant legal protocols and obligations to be established. The report recommended that national authorities develop their SWs to support regional integration through interoperability and that this should be taken into account at the design stage. It also warns of the growing competitive disadvantages that will affect countries that are lagging behind in this regard.

Although SWs are developed in stages and thus take considerable time to design and implement, there has been an almost exponential increase in recent years in both of these stages. For an SW to be considered "operational," it needs to meet the following criteria: the online platform is operating with only minimum errors; the system has an official name; it can be accessed via an official website; it must allow the electronic processing of customs forms; customs clearance can be completed at least in part online; and it connects customs authorities and agents electronically. If these processes are being 
developed but have not yet been implemented, the system is said to be in development. A total of 117 SWs were recorded in 2018, of which 41 are operational (figure 1) and 76 are in development. ${ }^{3}$

\section{Figure 1. Number of Operational SWs}

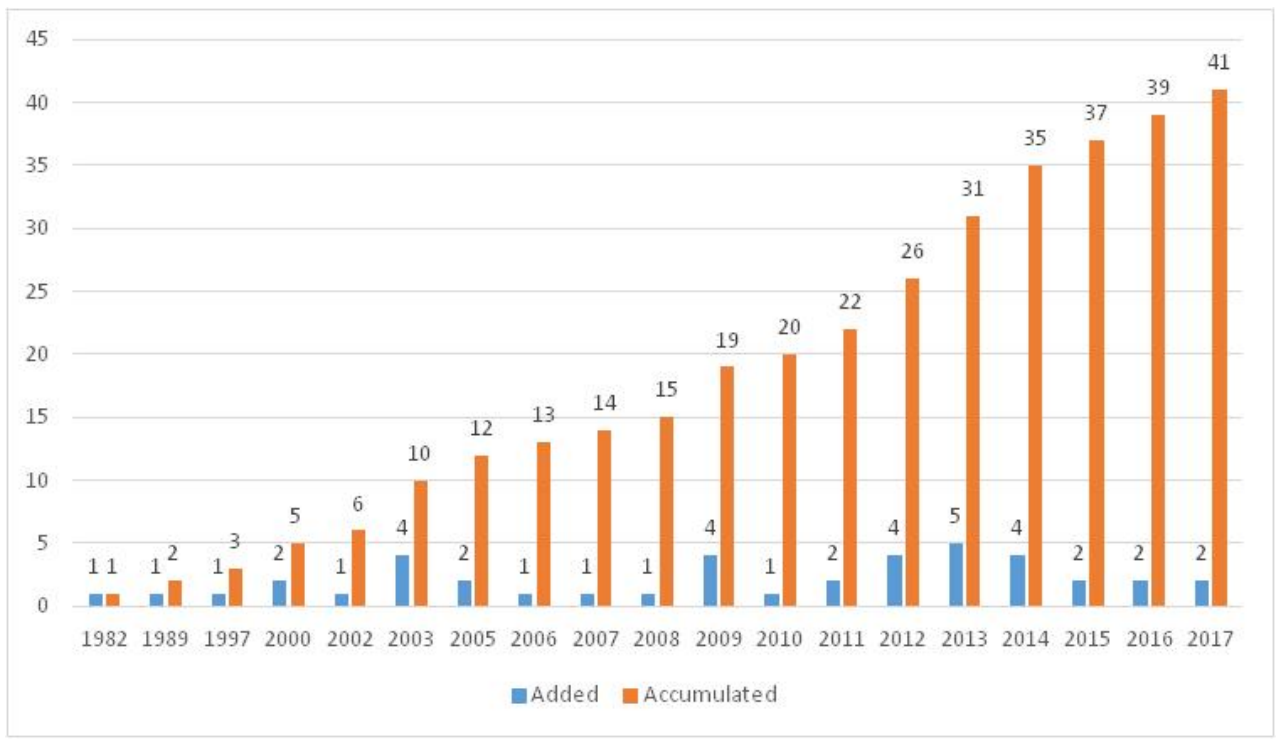

Source: Compiled by the authors using IFC-Doing Business Database

Figure 2 shows that half of the total operational SWs are in high-income countries and sub-Saharan Africa. High-income countries and those in Latin America are currently the most active in terms of developing SWs, as they account for 18 and 16 of the systems that have not yet been implemented, respectively.

Figure 2. Number of SWs by Region According to Operational Status

\footnotetext{
${ }^{3}$ There are 40 operational SWs for imports. This is because Paraguay has an operational SW for exports but is still developing one for imports. Tables A.1 and A.2 in the Appendix list the countries with operative SWs and with SWs in development, respectively.
} 


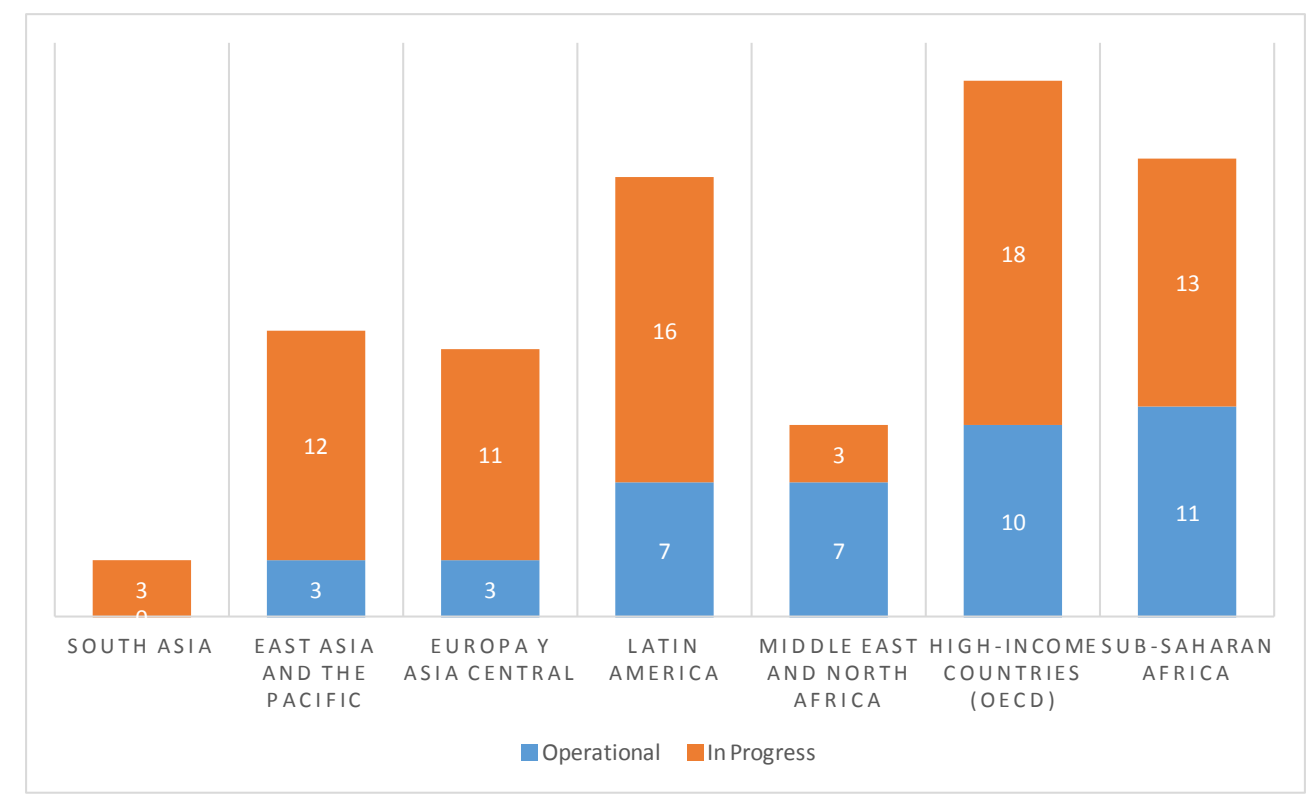

Source: Compiled by the authors using IFC-Doing Business Database

The evolution of SWs in recent years reflects countries' growing interest in combining SWs with the technologies of the Fourth Industrial Revolution, such as IoT (the Internet of Things), artificial intelligence, and, above all, blockchain. ${ }^{4}$ Despite this growing appeal, few empirical studies have been carried out to evaluate how these systems impact export performance. The existent studies are reviewed in the next section.

\section{Literature Review}

Because SWs are a relatively new tool, the available impact studies on them are also fairly recent. Tsen (2011) presents a descriptive assessment for SWs. Although the references are vague and lack a quantitative analysis, the study argues that "the national Single Window has been a success story"

\footnotetext{
${ }^{4}$ Suominen (2018) notes that blockchain technology has begun to be tested by the customs agencies of the United Kingdom, Korea, Singapore, Costa Rica, Mexico, Peru, and 15 countries in East Africa. Most of these already have operational SWs. UN/CEFACT (2018) has published a whitepaper on the subject that emphasizes the need to move toward including blockchain in some customs systems, such as Australia's, to create prototypes for SWs seeking to use this technology. WEF (2018) estimates that if blockchain technology is appropriately implemented, it would bring savings of up to $70 \%$ on stakeholders' operating costs.
} 
because they have simplified and automated business procedures and improved collaboration between government agencies and the private sector. The author observes that many countries' trade facilitation and logistical performance indicators have improved through SWs, although he does not provide concrete data to support this claim.

A survey of 177 countries published by Choi (2001) found that 15 agencies on average are involved in cross-border transactions. Building on this, a study commissioned by the European Parliament (2013) points to the need to move toward an SW to become more competitive, following the example set by South Korea, where the system has led to daily savings of US\$400 million. By introducing an SW, South Korea has cut down on the time those involved in foreign trade spend on filling out customs declarations by $30 \%$ to $40 \%$. In addition, the actual time spent on customs clearance dropped from over a day to just two minutes for exports and promoted two days to less than two hours for imports. ${ }^{5}$

In addition to these direct benefits, there also indirect ones. Linke (2012) states that simplifying customs procedures saves time, thus raising security standards by preventing fraud, smuggling, and other crimes linked to foreign trade that have a negative effect on competition both at home and abroad.

Volpe Martincus (2017) analyzes the impact that Costa Rica's SW has had by identifying specific shipments that were processed through the digital platform and shipments that were not, including information regarding the date on which each permit (and specific product) could begin to be processed through the SW. ${ }^{6}$ According to these estimates, for products for which permits are required, Costa Rica's SW system is associated with a $71.1 \%$ increase in export growth. In other words, this would imply that exports processed through the electronic single window would have a growth rate 1.4 percentage points higher than exports subject to the noncomputerized procedures. The author also estimates that in the

\footnotetext{
${ }^{5}$ European Parliament (2013).

${ }^{6}$ In Costa Rica, in addition to the national customs agency, a further 16 agencies play a part in the export process, issuing a total of 20 authorizations. The report describes how "until the mid-1990s all these entities used different documents, which had to be presented in person" and, as a consequence, "completing the formalities of the export process rarely took less than five days and often took much longer."
} 
absence of an SW, aggregate exports would have been $2 \%$ lower on average than they actually were between 2008 and 2013, which is equal to approximately $0.5 \%$ of the country's total GDP. ${ }^{7}$

Volpe Martincus (2017) arrives at similar results for Colombia, where the greater ease of importing goods from abroad that has come with the SW system has led to a sharp increase in imports, but argues that additional research is needed to establish how these arrangements work in other countries. According to Evans and Harrigan (2005), the effect of shorter delivery times is equivalent to an improvement in product quality, which in turn allows companies to increase the prices of their products and their export volumes.

WEF (2018) points out that Senegal's SW system has reduced time at customs from two weeks to a single day. This has brought the cost of border management down by $60 \%$ and the customs agency has had to reassign staff to other areas. Other studies on trade facilitation take the same approach, analyzing the impact of SWs on the number of days it takes to export or import products. The methodology that we propose below has not yet been used to measure how SWs impact trade performance.

\section{Impact on Trade}

\section{IV.1. Data, Variables, and Sources}

We will begin by describing the sources of the data used in the estimations. The data on SWs has been compiled from information from the Inter-American Development Bank (IADB) and from websites of ministries of foreign trade or the agency responsible for trade facilitation in each country in the sample. Two dummy variables were created using this information. The first $\left(s w_{-} o\right)$ takes the value of 1 when

\footnotetext{
${ }^{7}$ The study specifies that the new mechanism for processing permits was associated with a $22.4 \%$ increase in the growth rate of the number of buyers and a $43.5 \%$ increase in the growth rate of average sales per buyer.
} 
the exporter has an operational SW and 0 otherwise. The second $\left(s w_{-} d\right)$ is defined in the same way but focuses on the importer country. ${ }^{8}$

The trade data is from UNCTAD for 1995-2017. Bilateral imports were based on data from the reporting country as these tend to contain fewer errors and omissions than those on exports. GDP data in current US dollars and the populations of trading countries were taken from the World Bank World Development Indicators (WDI). The advantage of using country level data to assess the issue of single windows is that it mitigates some of the measurement errors and biases associated with firm-level measures (see Asiedu and Freeman, 2009), and all types of potential spillovers are implicitly captured at the aggregated export measures.

The geographical and cultural variables used to estimate the traditional gravity model are from CEPII. These include the geographical distance between country pairs, as a variable representing transportation costs; the area of each country in square kilometers; and a series of dichotomous variables that take the value of 1 when countries share an official language, share a border, have no access to the sea, or have colonial ties, and 0 otherwise. Dichotomous variables were also included that take the value of 1 if the exporting (importing) country is a member of the World Trade Organization, free trade agreements, or monetary unions, and 0 otherwise. The variables relating to free trade agreements and monetary unions have been updated from information compiled by De Sousa (2012) using the same sources cited by the authors. Table A.3 in the Appendix summarizes the variables used in the empirical analysis, including names, definitions, and sources. The data on the number of days and documents required to export or import goods were obtained from the World Bank's Doing Business

\footnotetext{
${ }^{8}$ We also considered another variable (sw), which takes the value of 1 if both the exporter and importer countries have operational SWs and 0 if they do not, however, given that only $1.3 \%$ of observations actually took the value of 1 (see table 1, final column), we did not include this bilateral variable in our empirical analysis.
} 
database and were only used in figures $2-5 .{ }^{9}$ Table 1 contains a summary of the main statistics for the variables used in the empirical model.

Table 1. Summary Statistics

\begin{tabular}{llllll}
\hline Variable & Obs & Mean & Std. Dev. & Min & Max \\
\hline lexp & 387,180 & 7.518 & 4.078 & -6.908 & 20.038 \\
Igdp_exp & 387,180 & 24.450 & 2.256 & 16.395 & 30.523 \\
Igdp_imp & 387,180 & 24.450 & 2.256 & 16.216 & 30.523 \\
Ipop_exp & 387,180 & 16.050 & 1.765 & 9.15599 & 21.039 \\
lpop_imp & 387,180 & 16.050 & 1.765 & 9.155 & 21.039 \\
Idist & 387,180 & 8.642 & 0.811 & 4.088 & 9.899 \\
lang & 387,180 & 0.151 & 0.358 & 0 & 1 \\
border & 387,180 & 0.023 & 0.148 & 0 & 1 \\
comcol & 387,180 & 0.094 & 0.291 & 0 & 1 \\
larea_exp & 387,180 & 11.894 & 2.263 & 3.332 & 16.117 \\
larea_imp & 387,180 & 11.894 & 2.263 & 3.332 & 16.117 \\
landlocked_exp & 387,180 & 0.185 & 0.388 & 0 & 1 \\
landlocked_imp & 387,180 & 0.185 & 0.388 & 0 & 1 \\
wto & 387,180 & 0.692 & 0.462 & 0 & 1 \\
sw_o & 387,180 & 0.105 & 0.307 & 0 & 1 \\
sw_d & 387,180 & 0.103 & 0.304 & 0 & 1 \\
sw_od & 387,180 & 0.013 & 0.114 & 0 & 1 \\
\hline
\end{tabular}

Note: The definitions of the variables can be found in Table A.3.

The figures that follow show how the distribution of exports varies depending on whether or not the exporter countries have an operational SW. Figure 3 shows the density function for exports in natural logarithms for four cases: when neither of the two trading countries has an SW, when only the exporter or only the importer country has an SW, and when both have an SW. As can be seen, when neither country has an SW (the solid line), the graph is more to the left, while when only the exporter (the dashed line) or importer (the dotted line) does, the density of exports shifts more to the right. This shift is greater for the exporter than for the importer. When both countries have SWs (the dash-dotted line), the density function is even further to the right than in the two previous cases. Consequently, this graphical representation indicates that the magnitude of trade flows is greater for countries with SWs than for those without them and that when both trading partners have operational SWs, this has a magnifying effect on their bilateral trade. However, we need to control for other factors that influence bilateral trade flows to confirm what the graphs suggest and discard other factors as being the cause of

\footnotetext{
${ }^{9}$ These were not used in the estimations as they are only available from 2004 onward.
} 
the difference between exports from the group of countries in question (operational SWs) and from the control group (no SWs).

\section{Figure 3. Density Function for Exports from Countries with and Without Single Windows}

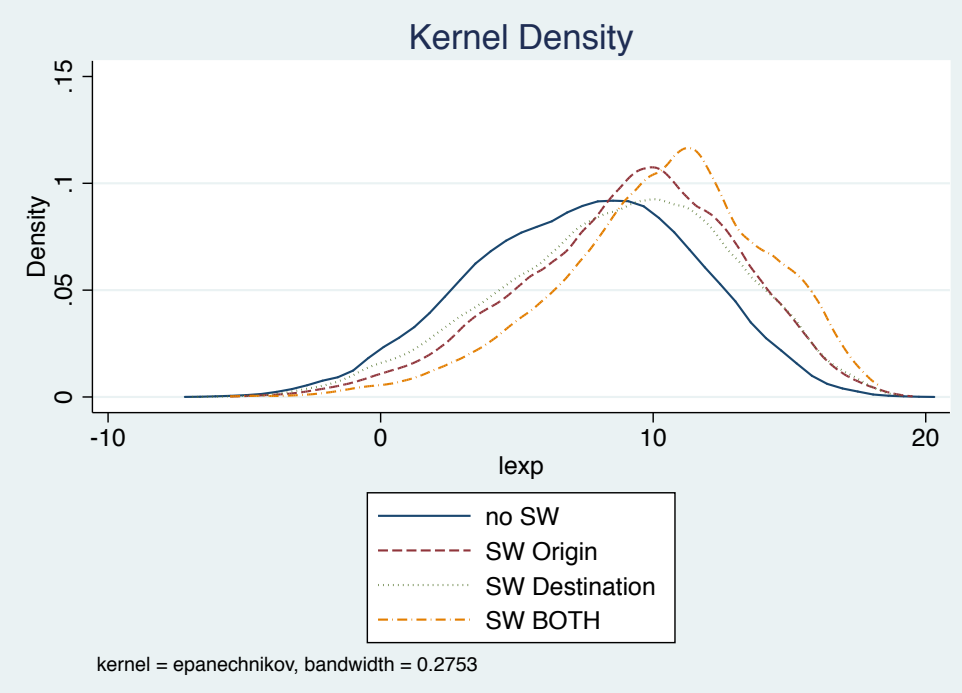

Note: $S W=$ Single window.

Before going on to present our empirical strategy, we will discuss the evolution of two selected variables that relate to the costs of trade, days needed to export/import and the number of documents required. The World Bank's Doing Business database lists the procedural requirements for exporting and importing a standardized cargo of goods. A record is kept of all compulsory official procedures (from the contractual agreement between the two parties to the delivery of the goods), as are the time and costs needed to complete the process, including the documents required for clearing goods across the border. Export procedures start when goods are packed in the factory and continue up to their clearance at the exit gate. Import procedures start with the arrival of the ship at the port of entry and finish when goods are delivered to their final destination.

This information was originally provided by local freight forwarders, shipping lines, customs agents, and port officials. To make the data comparable from one country to the next, various assumptions were made about the businesses and goods that are traded. The businesses included had to be located in the most populous city in the country and must have at least 200 employees. They are private limited 
liability companies that do not operate within an export processing zone or industrial park with special import and export privileges. The company must be entirely nationally owned and must export more than $10 \%$ of its sales. The product being traded must travel in full load, in a 20 -foot container, and must be nonhazardous and not include military goods. It must not require special transportation conditions, such as refrigeration, or special phytosanitary or environmental safety standards other than accepted international norms. Finally, the product must be included in the following Standard International Trade Classification (SITC) categories: SITC 65 (textile yarn and related products); SITC 84 (articles of apparel and clothing accessories); or SITC 07 (coffee, tea, cocoa, spices, and manufactures thereof).

Figures 4 and 5 show the distribution of the days needed to export and import, respectively, for countries with or without SWs and reveal that this distribution is more concentrated for exporters with SWs, and therefore has less variance and is significantly lower on average. The same is true for imports (figure 5).

Figure 4. Density Function for the Days Needed to Export from Countries with/without a Single Window

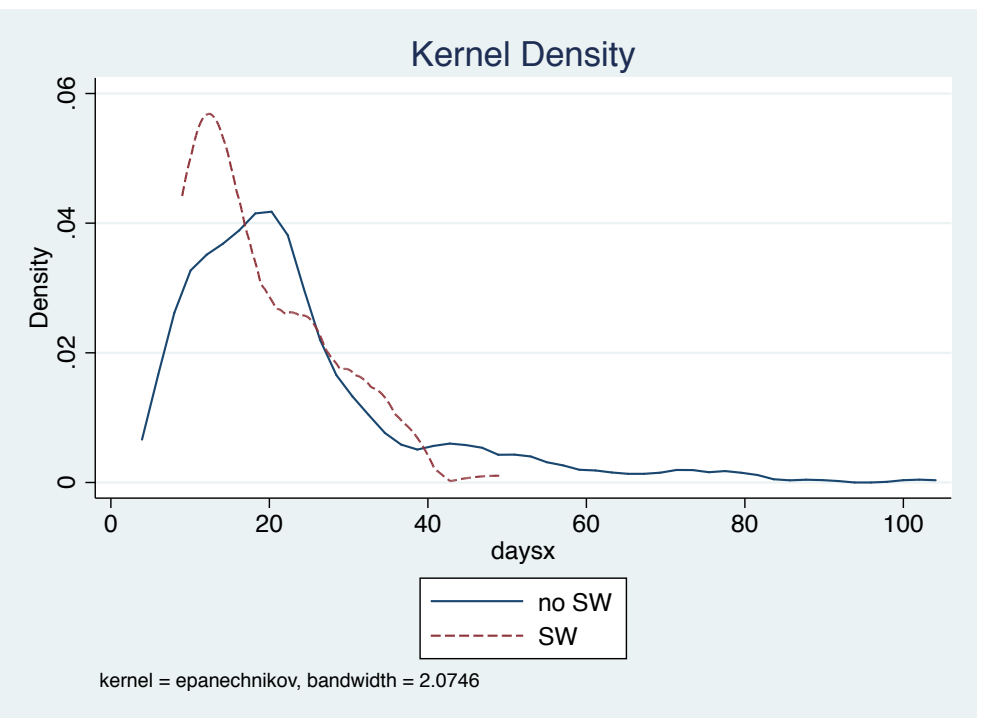


Figure 5. Density Function for the Days Needed to Import from Countries with/without a Single Window

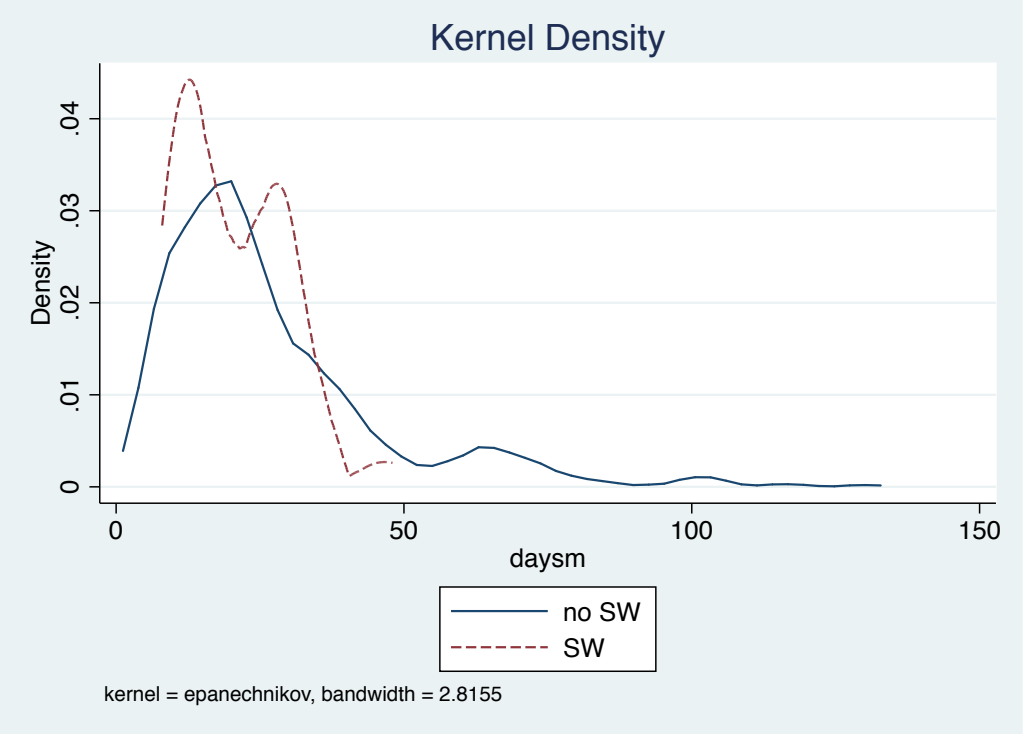

Likewise, the distribution of the average number of documents needed to export (figure 6) and import (figure 7) and the dispersion of this are also greater for exports from countries without SWs.

Figure 6. Density Function for the Number of Documents Needed to Export from Countries with/without a Single Window

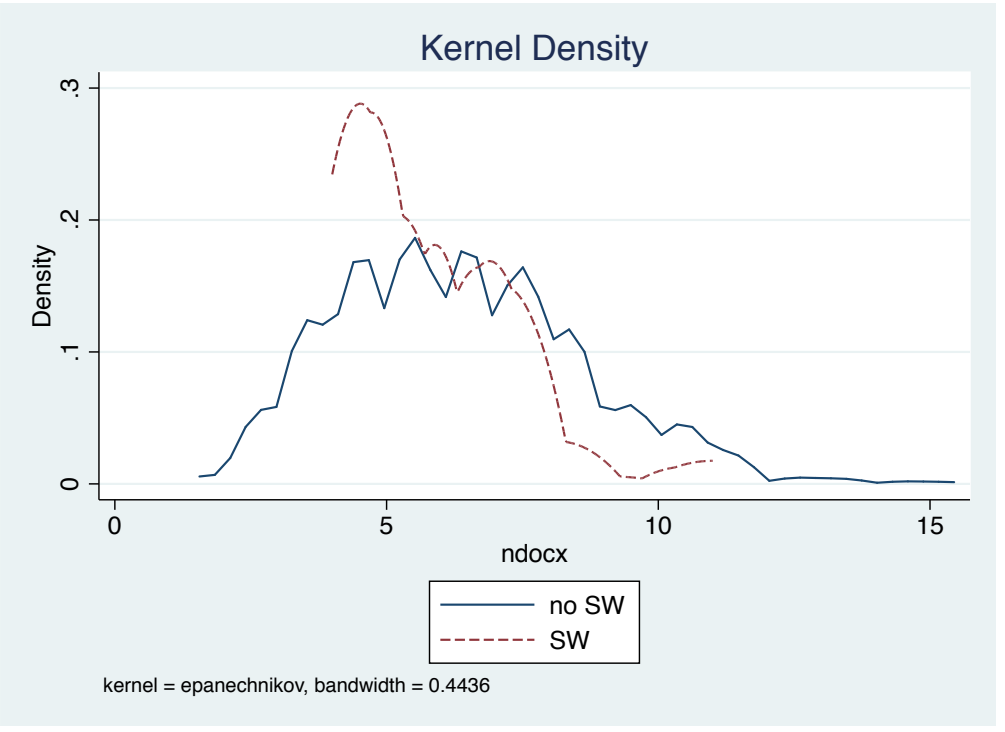


Figure 7. Density Function for the Number of Documents Needed to Import from Countries with/without a Single Window

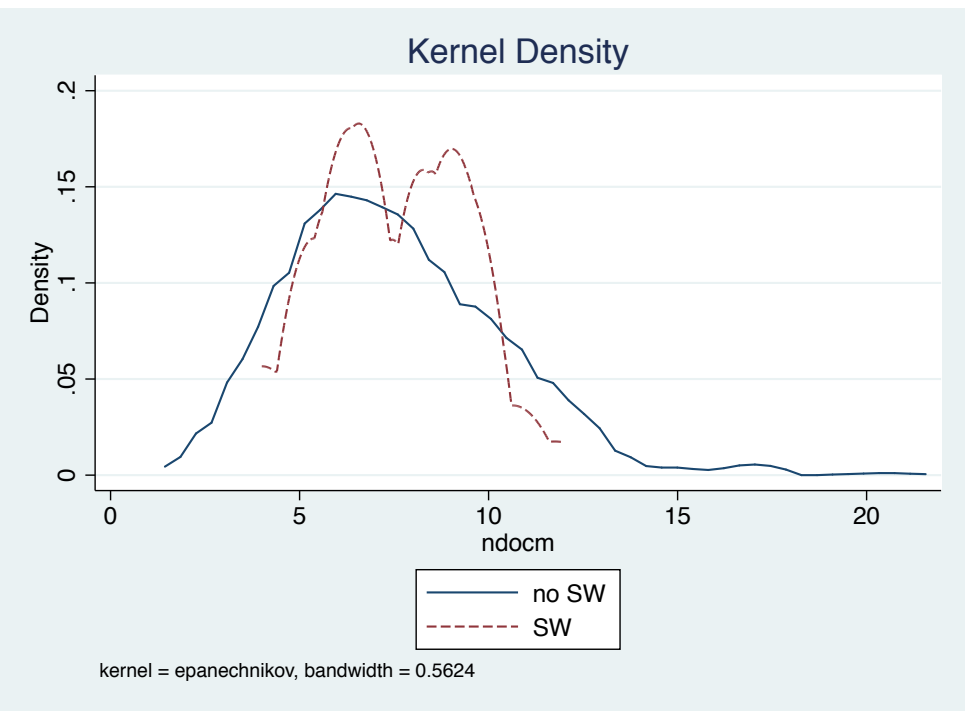

\section{IV.2. Empirical Model and Methodology}

The gravity model has been widely used to predict bilateral trade flows between countries in recent decades and is the go-to model for international trade analysis (Feenstra, 2004). It is a structural model with solid theoretical underpinnings (Eaton and Kortum, 2002; Anderson and Van Wincoop, 2003; Allen, Arkolakis, and Takahashi, 2014; Head and Mayer, 2014; Anderson et al., 2018) and is particularly appropriate for estimating the effects of trade policies and the importance of the costs of trade that are associated with distance and trade facilitation. Two of the model's most widely appreciated properties are its structure, which can flexibly accommodate the factors that affect trade, and its predictive power for aggregate trade flows. This is why we have used it in this study to estimate the effects of a specific trade facilitation measure on bilateral trade flows, namely the implementation of SWs.

When applied to trade, the gravity model predicts that the bilateral exports between two countries are directly proportionate to the product of their economic "mass" and inversely proportionate to the costs of trade (distance) between them. In its original form, the gravity model is as follows: 
$X_{i j t}=\frac{Y_{i t} Y_{j t}}{Y_{t}^{W}}\left(\frac{t_{i j t}}{P_{i t} P_{j t}}\right)^{1-\sigma}$

$X_{i j t}$ are the exports from country $i$ to country $j$ in period $t$ in current US dollars and $Y_{i t}\left(Y_{j t}\right)$ is the GDP of the exporter (importer) in period $t$, and $Y_{t}^{W}$ denotes global GDP. $\mathrm{T}_{\mathrm{ijt}}$ is the cost of trade between $i$ and $j$ in period $t$ and $\mathrm{P}_{\mathrm{it}}$ and $\mathrm{P}_{\mathrm{jt}}$ are price indices that reflect the multilateral resistance to trade of the exporter and the importer, respectively. Using natural logarithms, the model is given by:

$\ln X_{i j k t}=\ln Y_{i t}+\ln Y_{j t}-\ln Y_{t}^{W}+(1-\sigma) \ln t_{i j t}-(1-\sigma) \ln P_{i t}-(1-\sigma) \ln P_{j t}$ (2)

In model (2), we assume that trade costs are a linear function of the distance between trading countries and a series of factors that facilitate trade such as speaking a common language (Lang), sharing a border (Border), having colonial ties (Comcol), and being part of free trade agreements (RTA) or members of monetary unions (Comcur) or the WTO (WTO). The linear model to be estimated is:

$$
\begin{gathered}
\ln \left(X_{i j k t}\right)=\alpha_{0}+\alpha_{1} \ln Y_{i t}+\alpha_{2} \ln Y_{j t}+\alpha_{3} \ln \text { Dist }_{i j} \\
+\alpha_{4} \text { Landl }_{i}+\alpha_{5} \text { Landl }_{j}+\alpha_{6} \operatorname{lnArea}_{i}+\alpha_{7} \ln _{\text {Area }}+\alpha_{8} \text { Border }_{i j} \\
+\alpha_{9} \text { Lang }_{i j}+\alpha_{10} \text { Comcol }_{i j}+\alpha_{11} \text { WTO }_{i j t}+\alpha_{12} \text { Comcur }_{i j t}+\alpha_{13} \text { RTA }_{i j t}+\alpha_{14} \text { SW }_{i t}++\alpha_{15} \text { SW }_{i t}+u_{i j t}
\end{gathered}
$$

where, in addition to the variables described above, Landl indicates that the country has no access to the sea, Area denotes the area of country $i(j)$ in square kilometers, and SW indicates that $i$ or $j$ have SWs in period $t$.

The rapid ongoing development of new techniques for estimating the model, which are based on theoretical advances, has given rise to a series of practical recommendations that have been well documented in Head and Mayer (2014) and more recently in Larch et al. (2016) and Piermartini and Yotov (2016). Specifically, the factors that represent bilateral costs can be replaced by bilateral fixed effects (ij). Fixed effects that vary by exporter-time (it) and importer-time (jt) are included as a proxy for 
multilateral resistance, so variables such as GDP and SWs cannot be identified directly. ${ }^{10}$ Following on from this, to identify the effect of variables that vary by country and over time, such as SWs, two stages are estimated. In the first stage, the country-time effects are estimated from the following gravitational model:

$\ln X_{i j t}=\delta_{i j}+\tau_{i t}+\varphi_{j t}+\alpha_{1} T P_{i j t}+\varepsilon_{i j t}$ (4)

where the fixed (bilateral) effects associated with trade, $\delta_{i j}$, represent the time-invariant characteristics of the trade relationship between $i$ and $j$ and are included to avoid biases due to bilateral time-invariant unobservable factors that affect trade. Given that the influence of variables that are bilateral and timeinvariant-such as geographical distance, a shared language, or a shared border-is absorbed by fixed bilateral effects, it is impossible to estimate coefficients for these factors directly. $T P_{i j t}$ represents timevariable bilateral factors, such as being a member of a currency union (CU) or the World Trade Organization (WTO) or regional or bilateral trade agreements. Finally, $\varepsilon_{\mathrm{ijt}}$ is the error term and is assumed to be identically or independently distributed.

Exporter-time $\left(\tau_{i t}\right)$ and importer-time $\left(\varphi_{i t}\right)$ fixed effects represent all manner of trade barriers that are country-specific and vary over time. Outward and inward multilateral resistance should be controlled for, that is, third-party countries' barriers to trade that affect the costs of trade. The exporter-time and importer-time fixed effects were extracted from model $(4)^{11}$, and are used as dependent variables in a second stage. The following model was estimated for the export-time fixed effects in the second stage:

$$
\hat{\tau}_{i t}=\gamma_{i}+\beta_{1} \ln Y_{i t}+\beta_{2} \ln \text { Pop }_{i t}+\beta_{3} W T O_{i t}+\beta_{4} S W_{i t}+\beta_{4} L_{\text {andl }}+\beta_{5} \ln \text { Area }_{i}+\beta_{6} \sum_{j} w D_{i j}+\eta_{i t}
$$

\footnotetext{
${ }^{10}$ The direct effect on exports of variables that change by country and over time is subsumed in the exporter-time and importer-time fixed effects..

${ }^{11}$ The model (4) was also estimated using the Poisson Pseudo Maximum Likelihood (PPML) method, with different levels of exports, whereby zeros are included in the dependent variable and the method is robust to heteroskedasticity in the residues. The specification of the model is as follows: $X_{i j t}=\operatorname{Exp}\left[\delta_{i j}+\tau_{i t}+\varphi_{j t}+\right.$ $\left.\alpha_{1} T P_{i j t}\right] \varepsilon_{i j t}$.
} 
A similar model was estimated for importing countries $(j)$ for importer-time fixed effects $\left(\varphi_{i t}\right)$. To account for factors such as institutions, infrastructure, or cultural factors that vary slowly, the estimation includes unobservable country effects -fixed or random- effects. $Y_{i t}$ indicates the exporter's GDP. Pop refers to the population, WTO takes the value of 1 if the exporting country is a member of the World Trade Organization in period $t$. SW takes the value of 1 when the exporting country has an operational $\mathrm{SW}$ in period $t$. The export data is annual, but since it was largely possible to pinpoint the specific month in which each SW was opened, we have classified each SW as starting operations the same year if it was opened between January and June and the following year if it was opened between July and December.

Other variables that do not vary over time were included in the model estimated using random effects, such as whether the country has no access to the sea (Landl), the natural logarithm of the area in square kilometers (Area), the weighted average of the distance between it and all its trading partners (included in $\left.D_{i j}\right)$, and measures of cultural similarities $\left(D_{i j}\right)$ : how many partners it shares a language, border, or colonial relationship with.

\section{IV.3. Main Results}

The gravity model for exports between 176 countries $^{12}$ was estimated with annual data for 1995-2017. First, Table 2 shows the results obtained for the traditional gravity model estimated with the dependent variable in natural logarithms, so as to compare this with the two-stage model, which is the preferred option. Column (1) includes the country variables (income and area of the exporting country), and the bilateral variables (common border, common language, colonial ties, etc.) that tend to be included as facilitators of or impediments to bilateral trade, according to specification (3).

The first column shows that countries' income has unitary elasticity, as the theory predicts. The coefficient that was estimated for geographic distance is negative and significant and has a magnitude of

\footnotetext{
${ }^{12}$ The countries in the sample are listed in Appendix A.4.
} 
around 1 , indicating that a $1 \%$ increase in distance reduces trade by around $1.2 \%$. The dummy variables of sharing a border, language, or colonial ties facilitate trade, with a shared border playing the most significant role: neighboring countries trade $178 \%$ more than they do with other countries. The variable of interest-that is, whether or not the exporter or importer country or both have operational SWs-a reveals that the exporter alone has an operational SW then exports are $40 \%$ greater, if the importer alone has one, they are $38 \%$ greater, and if both countries have them, these two increases are combined. The second column shows the results that were obtained after including fixed effects for the exporter and the importer in the model to control for multilateral resistance that does not vary over time. It can be observed that the effect of SWs in just one country is considerably reduced for both the exporter (a one-third drop) and the importer (a two-thirds drop). However, when both countries have SWs there is a $40 \%$ increase in exports $(25+15)$. Similar results are obtained in column (3), which was estimated with fixed bilateral effects. Finally, column (4) shows the results when three groups of fixed effects are included simultaneously, as is specified in equation 4: origin-time, destination-time, and bilateral fixed effects. The first two groups of fixed effects were extracted from this model and used in the second stage of the estimation of model (5) from the previous section.

Table 2. Results of the Estimation of the Gravity Model

\begin{tabular}{|c|c|c|c|c|}
\hline VARIABLES & $\begin{array}{l}\text { (1) } \\
\text { InX_TFE }\end{array}$ & $\begin{array}{l}\text { (2) } \\
\text { InX_TCFE }\end{array}$ & $\begin{array}{l}\text { (3) } \\
\text { InX_BFE }\end{array}$ & $\begin{array}{l}\text { (4) } \\
\text { InX_BCTFE }\end{array}$ \\
\hline sw_o & $\begin{array}{l}0.338 * * * \\
(0.030)\end{array}$ & $\begin{array}{l}0.220 * * * \\
(0.023)\end{array}$ & $\begin{array}{l}0.205^{* * *} \\
(0.022)\end{array}$ & \\
\hline sw_d & $\begin{array}{l}0.321 * * * \\
(0.035)\end{array}$ & $\begin{array}{l}0.136^{* * *} \\
(0.024)\end{array}$ & $\begin{array}{l}0.135^{* * *} \\
(0.022)\end{array}$ & \\
\hline wto & $\begin{array}{l}0.399 * * * \\
(0.026)\end{array}$ & $\begin{array}{l}0.355 * * * \\
(0.030)\end{array}$ & $\begin{array}{l}0.276 * * * \\
(0.022)\end{array}$ & $\begin{array}{l}0.168^{* * *} \\
(0.031)\end{array}$ \\
\hline comcur & $\begin{array}{l}0.352 * * * \\
(0.094)\end{array}$ & $\begin{array}{l}0.083 \\
(0.094)\end{array}$ & $\begin{array}{l}0.214 * * * \\
(0.035)\end{array}$ & $\begin{array}{l}0.166^{* * *} \\
(0.024)\end{array}$ \\
\hline rta & $\begin{array}{l}0.879 * * * \\
(0.036)\end{array}$ & $\begin{array}{l}0.717 * * * \\
(0.033)\end{array}$ & $\begin{array}{l}0.185^{* * *} \\
(0.020)\end{array}$ & $\begin{array}{l}0.104^{* * *} \\
(0.012)\end{array}$ \\
\hline Igdp_exp & $\begin{array}{l}1.224 * * * \\
(0.006)\end{array}$ & $\begin{array}{l}0.322 * * * \\
(0.024)\end{array}$ & $\begin{array}{l}0.426 * * * \\
(0.023)\end{array}$ & \\
\hline Igdp_imp & $\begin{array}{l}0.974 * * * \\
(0.007)\end{array}$ & $\begin{array}{l}0.745^{* * *} \\
(0.020)\end{array}$ & $\begin{array}{l}0.810 * * * \\
(0.018)\end{array}$ & \\
\hline Idist & $\begin{array}{l}-1.156 * * * \\
(0.017)\end{array}$ & $\begin{array}{l}-1.446 * * * \\
(0.020)\end{array}$ & & \\
\hline lang & $\begin{array}{l}0.704 * * * \\
(0.037)\end{array}$ & $\begin{array}{l}0.729 * * * \\
(0.038)\end{array}$ & & \\
\hline
\end{tabular}




\begin{tabular}{|c|c|c|c|c|}
\hline border & $\begin{array}{l}1.025^{* * *} \\
(0.097)\end{array}$ & $\begin{array}{l}0.648 * * * \\
(0.098)\end{array}$ & & \\
\hline comcol & $0.815^{* * *}$ & $0.879 * * *$ & & \\
\hline larea_exp & $\begin{array}{l}-0.082^{* * *} \\
(0.006)\end{array}$ & & & \\
\hline larea_imp & $\begin{array}{l}-0.013^{* *} \\
(0.006)\end{array}$ & & & \\
\hline landl_exp & $\begin{array}{l}-0.512^{* * *} \\
(0.033)\end{array}$ & & & \\
\hline landl_imp & $\begin{array}{l}-0.420 * * * \\
(0.032)\end{array}$ & & & \\
\hline Time effects (TFE) & yes & yes & yes & \\
\hline Observations & 387,180 & 387,180 & 387,180 & 402,398 \\
\hline Adjusted R-squared & 0.671 & 0.739 & 0.154 & 0.879 \\
\hline Number of pairs & & & 27,242 & \\
\hline
\end{tabular}

Note: Robust standard errors in parentheses. ${ }^{* * *} \mathrm{p}<0.01,{ }^{* *} \mathrm{p}<0.05,{ }^{*} \mathrm{p}<0.1$. BCTFE denotes bilateral, exporter-time and importer and time fixed effects. A description of the variables is given in Table A.3.

Table 3 shows the results obtained from estimating model (5) for exporters -with random effects in the first column and with fixed country effects in the second. Columns (3) and (4) show similar results for importers $^{13}$. The results for the SWs are very similar to those presented in column (4) of Table 2 . When a country has an operational SW it exports $23 \%$ more than it did before opening this (column 2 ). If it is the importer that has the SW, exports are $14 \%$ higher than in the absence of this. Consequently, if both the importer and the exporter have operational SWs, according to this estimation, trade increases by around 37\%. This validates the result obtained in the process of estimating Table 2 in columns (2) and (3), where the result was $40 \%$.

Table 3. Multilateral Resistance and Single Windows. Second Step Results (first Log.Log)

\begin{tabular}{lllll}
\hline $\begin{array}{l}\text { Dep. Var: MRT } \\
\text { from first step§ }\end{array}$ & (1) Exporter & (2) Exporter & (3) Importer & (4) Importer \\
\hline IND. Var: & FE1_2RE & FE1_2FE & FE2_2RE & FE2_2FE \\
sw & & & & \\
& $0.226^{* * *}$ & $0.210^{* * *}$ & $0.144^{* * *}$ & $0.134^{* * *}$ \\
Igdp & $(0.071)$ & $(0.073)$ & $(0.051)$ & $(0.047)$ \\
& $0.668^{* * *}$ & $0.412^{* * *}$ & $0.775^{* * *}$ & $0.725^{* * *}$ \\
Ipop & $(0.054)$ & $(0.083)$ & $(0.036)$ & $(0.061)$ \\
& $0.149 *$ & -0.159 & $0.265^{* * *}$ & 0.318 \\
wto & $(0.090)$ & $(0.413)$ & $(0.071)$ & $(0.237)$ \\
& 0.122 & 0.126 & 0.043 & 0.066
\end{tabular}

\footnotetext{
${ }^{13}$ A regression based Hausman test indicated that we cannot reject the ortogonality between the country effects and the regressors. It can be seen that the coefficients of the SW variable are very similar. Therefore, results in columns (1) and (3) are expected to provide consistent and more efficient estimates, being results in columns (2) and (4) also consistent.
} 


\begin{tabular}{lllll} 
& $(0.111)$ & $(0.129)$ & $(0.107)$ & $(0.115)$ \\
larea & -0.007 & & $-0.110^{* *}$ & \\
& $(0.059)$ & & $(0.044)$ & \\
landl & $-0.671^{* * *}$ & & $-0.333^{* * *}$ & \\
& $(0.197)$ & & $(0.109)$ & \\
Idist & -0.045 & & $-0.171^{* * *}$ & \\
& $(0.034)$ & & $(0.026)$ & \\
lang & $-0.164^{* *}$ & & -0.050 & \\
& $(0.079)$ & & $(0.048)$ & \\
border & -0.018 & & $-0.299^{* * *}$ & \\
& $(0.081)$ & & $(0.060)$ & \\
comcol & -0.153 & & 0.001 & \\
& $(0.095)$ & & $(0.063)$ & \\
Time effects (TFE) & yes & yes & yes & yes \\
Number of id & 26,425 & 26,425 & 26,326 & 26,326 \\
Number of obs & 394,452 & 394,452 & 393,740 & 393,740 \\
within R-squared & & 0.668 & & 0.340 \\
\hline
\end{tabular}

Note: Robust standard errors (se) in parentheses. $* * * p<0.01, * * p<0.05, * p<0.1$. § Obtained from regression in column (4) in table 2. A description of the variables is given in Table A.3. Bootstrapped se using 1000 repetitions.

\section{IV.4. Robustness Checks}

As robustness checks we have estimated different versions of the gravity model using a PPML estimation technique, as proposed in the related literature (Head and Mayer, 2014; Larch et al, 2016; among others). The first stage estimations are presented in the Appendix (Table A5). The results for the target variable indicate that the coefficient of the SWs dummies is positive and statistically significant in the first column of Table A5, when only time fixed effects are considered. However, the introduction of exporter and importer fixed effects or pair fixed effects render the coefficients non-statistically significant. In any case, when the model is estimated in two stages, the results obtained for the second stage, reported in Table 4, also suggest that SWs stimulate trade. Nevertheless, the magnitude of the effects is considerably lower, possibly due to the inclusion of zeros in the dependent variable in the estimation. The effect of the introduction of SW indicates that exports increase by around 1 percent, whereas imports increase only by around 0.2 percent.

\section{Table 4. Multilateral Resistance and Single Windows. Second Step Results (first PPML)}

\begin{tabular}{lllll}
\hline & (1)Exporter & (2)Exporter & (3)Importer & (4)Importer \\
$\begin{array}{l}\text { Dep. Var: MRT from } \\
\text { first step PPML }\end{array}$ & FE1_2RE & FE1_2FE & FE2_2RE & FE2_2FE
\end{tabular}




\begin{tabular}{|c|c|c|c|c|}
\hline \multicolumn{5}{|l|}{ IND. Var: } \\
\hline \multirow[t]{2}{*}{ sw } & $0.009 * * *$ & $0.009 * * *$ & $0.002 * * *$ & $0.002 * * *$ \\
\hline & $(0.001)$ & $(0.001)$ & $(0.000)$ & $(0.000)$ \\
\hline \multirow[t]{2}{*}{ Igdp } & $0.017 * * *$ & $0.011 * * *$ & $0.009 * * *$ & $0.009 * * *$ \\
\hline & $(0.001)$ & $(0.001)$ & $(0.000)$ & $(0.000)$ \\
\hline \multirow[t]{2}{*}{ Ipop } & $-0.002^{*}$ & $-0.014 * * *$ & $-0.007 * * *$ & $-0.008 * * *$ \\
\hline & $(0.001)$ & $(0.002)$ & $(0.001)$ & $(0.001)$ \\
\hline \multirow[t]{2}{*}{ wto } & $-0.010 * * *$ & $-0.010 * * *$ & $0.002 * * *$ & $0.002 * * *$ \\
\hline & $(0.001)$ & $(0.001)$ & $(0.000)$ & $(0.000)$ \\
\hline \multirow[t]{2}{*}{ larea } & $0.011^{* * *}$ & & $0.003 * * *$ & \\
\hline & $(0.001)$ & & $(0.000)$ & \\
\hline \multirow[t]{2}{*}{ landl } & $-0.031 * * *$ & & $-0.011 * * *$ & \\
\hline & $(0.005)$ & & $(0.001)$ & \\
\hline \multirow[t]{2}{*}{ Idist } & 0.002 & & $-0.006 * * *$ & \\
\hline & $(0.003)$ & & $(0.001)$ & \\
\hline \multirow[t]{2}{*}{ lang } & $0.012 * *$ & & $0.004 * * *$ & \\
\hline & $(0.006)$ & & $(0.001)$ & \\
\hline \multirow[t]{2}{*}{ border } & 0.013 & & $-0.015^{* * *}$ & \\
\hline & $(0.015)$ & & $(0.004)$ & \\
\hline \multirow[t]{2}{*}{ comcol } & $-0.095 * * *$ & & $0.007 * * *$ & \\
\hline & $(0.005)$ & & $(0.002)$ & \\
\hline Time effects (TFE) & yes & yes & yes & yes \\
\hline Number of id & 27,745 & 27,745 & 27,184 & 27,184 \\
\hline Number of obs & 395,909 & 395,909 & 395,184 & 395,184 \\
\hline Within R-squared & & 0.010 & & 0.032 \\
\hline
\end{tabular}

Further robustness checks consisted on estimated several models including interactions between the target variable, the SW dummy, and several regressors. We first interacted it with the level of per capita income, to see whether the effect was heterogeneous for developed and developing countries, but the interaction term was not statisitically significant. Next we consider whether the effect was different for countries in which the use of the SW is compulsory, namely, Finland, Mauritius and Senegal, and again no differences were found ${ }^{14}$. Finally, we test whether the effect differ by geographically and interacted the SW dummies with continental dummies and the results are shown in Table 5 for the fixed effects model, similar to the one estimated in Table 3, columns (2) and (4). The only interaction term that show statistically significance is the one for the Asian continent, indicating that when the importer has a SW

\footnotetext{
${ }^{14}$ Results are available upon request from the authors.
} 
and trade is between Asian countries, the effect is significantly higher than for the average exporter and of the order of 22 percent more exports than the effect for trade between European countries (Europe is the default).

Table 5. Multilateral Resistance and Single Windows by continent. Second Step Results (first OLS)

\begin{tabular}{|c|c|c|}
\hline Second step: Dep var. MRT & (1) Exporter & (2) ImporteI \\
\hline IND. VARIABLES & FE1_2FE & FE2_2FE \\
\hline \multirow[t]{2}{*}{ Igdp } & $0.412 * * *$ & $0.725^{* * *}$ \\
\hline & $(0.083)$ & $(0.061)$ \\
\hline \multirow[t]{2}{*}{ Ipop } & -0.158 & 0.321 \\
\hline & $(0.413)$ & $(0.237)$ \\
\hline \multirow[t]{2}{*}{ wto } & 0.126 & 0.066 \\
\hline & (0.129) & $(0.115)$ \\
\hline \multirow[t]{2}{*}{ sw } & $0.214 * * *$ & $0.134 * * *$ \\
\hline & $(0.074)$ & $(0.048)$ \\
\hline \multirow[t]{2}{*}{ sw_africa } & -0.108 & -0.071 \\
\hline & $(0.102)$ & $(0.065)$ \\
\hline \multirow[t]{2}{*}{ sw_america } & 0.038 & 0.033 \\
\hline & $(0.067)$ & $(0.050)$ \\
\hline \multirow[t]{2}{*}{ sw_asia } & -0.129 & $0.221 * *$ \\
\hline & $(0.102)$ & $(0.088)$ \\
\hline Observations & 394,452 & 393,740 \\
\hline Number of id1 & 26,425 & 26,326 \\
\hline Adjusted R-squared & 0.668 & 0.340 \\
\hline $\begin{array}{l}\text { Robust standard errors in par } \\
p<0.1 \text {. }\end{array}$ & $1, * * p<0.0$ & \\
\hline
\end{tabular}

The empirical evidence shows that operational SWs contribute to reducing the number of documents needed to export and import and the time required to complete a foreign trade operation and have a positive impact on trade performance. 
Implementing SWs can increase trade between countries by around 37 percent when both the importer and the exporter have operational SWs and can bring about increases of 23 percent in exports and 14 percent in imports when only one of the two partners has an SW. Other specifications of the model that include zero trade flows show lower the estimated effect, but these are always positive and statistically significant, and are always higher if both the importer and exporter countries have operational SWs.

This impact is a consequence of lower costs, increased competitiveness, the appearance of new agents, and the consequent increase in the volumes of trade and in the time involved in this, which enables more operations to be performed during the same period.

The line of research that this study has opened up points to a need for quantitative estimations of the impact of SWs on export performance. Future studies that build on this one might analyze whether trade agreements help leverage the benefits of SWs, whether SWs are more effective in developing countries than in developed ones, and what other factors play a part in maximizing the gains from implementing SWs.

We also leave for further research a more exhaustive impact analysis on interoperability, in which new technologies like blockchain are beginning to play a fundamental role. International bodies also have a significant part to play in this process, for example by helping to establish guidelines for data harmonization; analyzing business processes, a prerequisite for effective harmonization; or by creating common regulatory frameworks for SWs that are part of the network. ${ }^{15}$ Without this harmonization and standardization, interoperability will remain out of reach for countries that have yet to implement SWs, and the substantial trade gains from this facilitation tool will remain in the hands of economies that pioneered the implementation of SWs.

\footnotetext{
${ }^{15}$ Tsen (2011) claims that although the ports of Hamburg, Mumbai, Singapore, and Shanghai have SWs, they use different dataset types, which prevents them from being interoperable.
} 


\section{References}

Ahnh, K. 2011. "Korean u-Port Project." KLNET.

Available at: https://artnet.unescap.org/tid/projects/tfforum11_klnet.pdf.

Allen, T., Arkolakis, C., and Takahashi, Y. 2014. "Universal Gravity." NBER Working Paper No. 20787. Cambridge: National Bureau of Economic Research.

Anderson, J., and Van Wincoop, E. 2003. "Gravity with Gravitas: A Solution to the Border Puzzle." American Economic Review 93(1), 170-192.

Anderson, J., Larch, M., Yotov, Y.V. 2018. "GEPPML: General Equilibrium Analysis with PPML." The World Economy 41(10), 2750-2782.

Asiedu, E. and Freeman, J. 2009. "The Effect of Corruption on Investment Growth: Evidence from firms in Latin America, Sub-Saharan Africa and Transition countries". Review of Development Economics 13(2): 200-214.

Bernal Turnes, P. 2015. "Interoperabilidad de las ventanillas únicas." Paper presented at the 7th Latin American and Caribbean Regional Meeting on Single Windows for Foreign Trade, Montevideo. Available at: http://www.sela.org/media/1998389/paloma-bernal-uncefat.pdf.

Choi, J., 2011. "A Survey of Single Window Implementation", WCO Research Document 17. Brussels: World Customs Organization.

De Sousa, J. 2012. "The Currency Union Effect on Trade is Decreasing Over Time." Economics Letters 117(3): 917-920.

Eaton, J., and Kortum, S. 2002. "Technology, Geography, and Trade." Econometrica 70(5): 1741-1779.

European Commission. 2015. "Evaluation of the Electronic Customs Implementation in the EU." Final Report, January 21.

European Parliament. 2012. "Implementation of the Modernised Customs Code." Directorate General for Internal Policies, February.

European Parliament. 2013. "Ubiquitous Developments of the Digital Single Market." Study IP/A/IMCO/ST/2013_02, PE 507.481, October.

Evans, C. and J. Harrigan 2005. "Distance, Time, and Specialization: Lean Retailing in General Equilibrium." American Economic Review 95(1): 292-313.

Feenstra, R. 2004. Advanced International Trade: Theory and Evidence. Princeton: Princeton University Press.

Head, K., and Mayer, T. 2014. "Gravity Equations: Workhorse, Toolkit, and Cookbook." In: G. Gopinath, E. Helpman, and K. Rogoff, editors. Handbook of International Economics, Vol. 4. Amsterdam: Elsevier.

Larch, M.; Yotov, Y.V., Piermartini, R., Monteiro, J.-A. 2016. "An Advanced Guide to Trade Policy Analysis: The Structural Gravity Model." World Trade Organization, Geneva.

Linke, M. 2012. "Connecting Logistics Networks Globally Via the UN Single Window Concept." Journal of Globalization Studies 3(2): 139-154. 
Piermartini, R. and Yotov, Y. 2016. "Estimating Trade Policy Effects with Structural Gravity." WTO Working Paper No. ERSD-2016-10. World Trade Organization, Economic Research and Statistics Division.

Suominen, K., Chatzky, A., Reinsch, W. and Robison, J. 2018. "Harnessing Blockchain for American Business and Prosperity." Center for Strategic and International Studies (CSIS). Available at: https://www.csis.org/analysis/harnessing-blockchain-american-business-and-prosperity.

Tsen, K.K.T 2011. "Ten Years of Single Window Implementation: Lessons Learned for the Future". Paper presented at the conference on Connecting International Trade-Single Windows and Supply Chains in the Next Decade, UNECE.

UNECE. 2003. "The Single Window Concept." United Nations Economic Commission for Europe (UNECE). United Nations, Geneva.

UN/CEFACT. 2005. "Recommendation 33, Establishing a Single Window to Enhance the Efficient Exchange of Information Between Trade and Government." Centre for Trade Facilitation and Electronic Business. International Trade Procedures Working Group.

UN/CEFACT. 2017. "Recommendation 36, Single Window Interoperability." Available at: http://www.unece.org/fileadmin/DAM/trade/Publications/ECE-TRADE-431E_Rec36.pdf.

UN/CEFACT. 2018. "Blockchain Project." United Nations Centre for Trade Facilitation and Electronic Business, Blockchain White Paper on the Technical Applications of Blockchain to United Nations Centre for Trade Facilitation and Electronic Business Deliverables, UN/CEFACT.

UN/CEFACT. 2019. "Case Studies on Implementing a Single Window." Working Draft. Available at: https://www.unece.org/fileadmin/DAM/cefact/single_window/draft_160905.pdf

Volpe Martincus, C. 2017. Out of the Border Labyrinth: An Assessment of Trade Facilitation Initiatives in Latin America and the Caribbean. Washington, DC: IADB.

WEF. 2018. "Trade Tech-A New Age for Trade and Supply Chain Finance." White paper, September.

Widdowson, David; Blegen, Bryce; Short, Geoff; Lewis, Gareth; Garcia-Godos, Eduardo; Kashubsky, Mikhail. 2019. "World Customs Journal Single window in the context of the WTO Trade Facilitation Agreement". World Customs Journal. Vol.13: pp.101-128.

World Bank. 2014. "Implementing Trade Single Windows in Singapore, Colombia and Azerbaijan." Doing Business 2014. 


\section{Appendix}

Table A.1. Countries with operational SW

\begin{tabular}{|c|c|c|c|}
\hline & Country & Region & Income level \\
\hline 1 & Australia & High income: OECD & High income \\
\hline 2 & Azerbaijan & Europe \& Central Asia & Upper middle income \\
\hline 3 & Bahrain & Middle East \& North Africa & High income \\
\hline 4 & Benin & Sub-Saharan Africa & Low income \\
\hline 5 & Brazil & Latin America \& Caribbean & Upper middle income \\
\hline 6 & Cameroon & Sub-Saharan Africa & Lower middle income \\
\hline 7 & Colombia & Latin America \& Caribbean & Upper middle income \\
\hline 8 & Côte d'Ivoire & Sub-Saharan Africa & Lower middle income \\
\hline 9 & Costa Rica & Latin America \& Caribbean & Upper middle income \\
\hline 10 & Ecuador & Latin America \& Caribbean & Upper middle income \\
\hline 11 & Finland & High income: OECD & High income \\
\hline 12 & France & High income: OECD & High income \\
\hline 13 & Germany & High income: OECD & High income \\
\hline 14 & Ghana & Sub-Saharan Africa & Lower middle income \\
\hline 15 & Indonesia & East Asia \& Pacific & Lower middle income \\
\hline 16 & Iran, Islamic Rep. & Middle East \& North Africa & Upper middle income \\
\hline 17 & Israel & High income: $O E C D$ & High income \\
\hline 18 & Italy & High income: OECD & High income \\
\hline 19 & Japan & High income: OECD & High income \\
\hline 20 & Kenya & Sub-Saharan Africa & Low income \\
\hline 21 & Korea, Rep. & High income: OECD & High income \\
\hline 22 & Macedonia, FYR & Europe \& Central Asia & Upper middle income \\
\hline 23 & Madagascar & Sub-Saharan Africa & Low income \\
\hline 24 & Mauritius & Sub-Saharan Africa & Upper middle income \\
\hline 25 & Mexico & Latin America \& Caribbean & Upper middle income \\
\hline 26 & Morocco & Middle East \& North Africa & Lower middle income \\
\hline 27 & Mozambique & Sub-Saharan Africa & Low income \\
\hline 28 & New Zealand & High income: OECD & High income \\
\hline 29 & Oman & Middle East \& North Africa & High income \\
\hline 30 & Paraguay & Latin America \& Caribbean & Lower middle income \\
\hline 31 & Portugal & High income: OECD & High income \\
\hline 32 & Qatar & Middle East \& North Africa & High income \\
\hline 33 & Rwanda & Sub-Saharan Africa & Low income \\
\hline 34 & Senegal & Sub-Saharan Africa & Low income \\
\hline 35 & Singapore & East Asia \& Pacific & High income \\
\hline 36 & Taiwan, China & East Asia \& Pacific & High income \\
\hline 37 & Togo & Sub-Saharan Africa & Low income \\
\hline 38 & Trinidad and Tobago & Latin America \& Caribbean & High income \\
\hline 39 & Tunisia & Middle East \& North Africa & Lower middle income \\
\hline 40 & Turkey & Europe \& Central Asia & Upper middle income \\
\hline 41 & United Arab Emirates & Middle East \& North Africa & High income \\
\hline
\end{tabular}

Source: Compiled by the authors using the IFC-Doing Business Database. 
Table A.2. Countries with SW in progress

\begin{tabular}{|c|c|c|c|}
\hline & Country & Region & Income level \\
\hline 1 & Albania & Europe \& Central Asia & Upper middle income \\
\hline 2 & Argentina & Latin America \& Caribbean & Upper middle income \\
\hline 3 & Armenia & Europe \& Central Asia & Lower middle income \\
\hline 4 & Bahamas, The & Latin America \& Caribbean & High income \\
\hline 5 & Barbados & Latin America \& Caribbean & High income \\
\hline 6 & Belgium & High income: OECD & High income \\
\hline 7 & Bolivia & Latin America \& Caribbean & Lower middle income \\
\hline 8 & Brunei Darussalam & East Asia \& Pacific & High income \\
\hline 9 & Burkina Faso & Sub-Saharan Africa & Low income \\
\hline 10 & Burundi & Sub-Saharan Africa & Low income \\
\hline 11 & Cambodia & East Asia \& Pacific & Lower middle income \\
\hline 12 & Canada & High income: OECD & High income \\
\hline 13 & Chile & High income: OECD & High income \\
\hline 14 & China & East Asia \& Pacific & Upper middle income \\
\hline 15 & Congo, Dem. Rep. & Sub-Saharan Africa & Low income \\
\hline 16 & Congo, Rep. & Sub-Saharan Africa & Lower middle income \\
\hline 17 & Czech Republic & High income: OECD & High income \\
\hline 18 & Denmark & High income: OECD & High income \\
\hline 19 & Dominican Republic & Latin America \& Caribbean & Upper middle income \\
\hline 20 & El Salvador & Latin America \& Caribbean & Lower middle income \\
\hline 21 & Estonia & High income: OECD & High income \\
\hline 22 & Fiji & East Asia \& Pacific & Upper middle income \\
\hline 23 & Georgia & Europe \& Central Asia & Lower middle income \\
\hline 24 & Greece & High income: OECD & High income \\
\hline 25 & Guatemala & Latin America \& Caribbean & Lower middle income \\
\hline 26 & Guinea & Sub-Saharan Africa & Low income \\
\hline 27 & Guyana & Latin America \& Caribbean & Upper middle income \\
\hline 28 & Honduras & Latin America \& Caribbean & Lower middle income \\
\hline 29 & Hong Kong SAR, China & East Asia \& Pacific & High income \\
\hline 30 & Iceland & High income: OECD & High income \\
\hline 31 & India & South Asia & Lower middle income \\
\hline 32 & Jamaica & Latin America \& Caribbean & Upper middle income \\
\hline 33 & Jordan & Middle East \& North Africa & Lower middle income \\
\hline 34 & Kazakhstan & Europe \& Central Asia & Upper middle income \\
\hline 35 & Kyrgyz Republic & Europe \& Central Asia & Low income \\
\hline 36 & Lao PDR & East Asia \& Pacific & Lower middle income \\
\hline 37 & Lithuania & Europe \& Central Asia & High income \\
\hline 38 & Luxembourg & High income: OECD & High income \\
\hline 39 & Malaysia & East Asia \& Pacific & Upper middle income \\
\hline 40 & Mali & Sub-Saharan Africa & Low income \\
\hline 41 & Malta & Middle East \& North Africa & High income \\
\hline 42 & Mauritania & Sub-Saharan Africa & Lower middle income \\
\hline 43 & Mongolia & East Asia \& Pacific & Lower middle income \\
\hline 44 & Myanmar & East Asia \& Pacific & Low income \\
\hline 45 & Namibia & Sub-Saharan Africa & Upper middle income \\
\hline 46 & Nepal & South Asia & Low income \\
\hline 47 & Netherlands & High income: OECD & High income \\
\hline 48 & Nicaragua & Latin America \& Caribbean & Lower middle income \\
\hline 49 & Nigeria & Sub-Saharan Africa & Lower middle income \\
\hline 50 & Pakistan & South Asia & Lower middle income \\
\hline 51 & Panama & Latin America \& Caribbean & Upper middle income \\
\hline
\end{tabular}




\begin{tabular}{llll}
52 & Peru & Latin America \& Caribbean & Upper middle income \\
53 & Philippines & East Asia \& Pacific & Lower middle income \\
54 & Poland & High income: OECD & High income \\
55 & Puerto Rico (U.S.) & Latin America \& Caribbean & High income \\
56 & Romania & Europe \& Central Asia & Upper middle income \\
57 & Russian Federation & Europe \& Central Asia & Upper middle income \\
58 & São Tomé and Príncipe & Sub-Saharan Africa & Lower middle income \\
59 & Saudi Arabia & Middle East \& North Africa & High income \\
60 & Slovak Republic & High income: OECD & High income \\
61 & Slovenia & High income: OECD & High income \\
62 & Spain & High income: OECD & High income \\
63 & St. Kitts and Nevis & Latin America \& Caribbean & High income \\
64 & Sweden & High income: OECD & High income \\
65 & Switzerland & High income: OECD & High income \\
66 & Tajikistan & Europe \& Central Asia & Low income \\
67 & Tanzania & Sub-Saharan Africa & Low income \\
68 & Thailand & East Asia \& Pacific & Upper middle income \\
69 & Uganda & Sub-Saharan Africa & Low income \\
70 & Ukraine & Europe \& Central Asia & Lower middle income \\
71 & United Kingdom & High income: OECD & High income \\
72 & United States & High income: OECD & High income \\
73 & Uruguay & Latin America \& Caribbean & High income \\
74 & Uzbekistan & Europe \& Central Asia & Lower middle income \\
75 & Vietnam & East Asia \& Pacific & Lower middle income \\
76 & Zambia & Sub-Saharan Africa & Lower middle income \\
\hline
\end{tabular}

Source: Compiled by the authors using IFC-Doing Business Database. 
Table A.3. Description of Variables

\begin{tabular}{|c|c|c|}
\hline Variable & Definition & Source \\
\hline lexp & Natural logarithm of exports in current US dollars & UNCTAD \\
\hline Igdp_exp & $\begin{array}{l}\text { Natural logarithm of the exporter country's GDP in current } \\
\text { US dollars }\end{array}$ & WDI, World Bank \\
\hline Igdp_imp & $\begin{array}{l}\text { Natural logarithm of the importer country's GDP in current } \\
\text { US dollars }\end{array}$ & WDI, World Bank \\
\hline Ipop_exp & $\begin{array}{l}\text { Natural logarithm of the exporter country's population in } \\
\text { numbers of inhabitants }\end{array}$ & WDI, World Bank \\
\hline Ipop_imp & $\begin{array}{l}\text { Natural logarithm of the exporter country's population in } \\
\text { numbers of inhabitants }\end{array}$ & WDI, World Bank \\
\hline Idist & $\begin{array}{l}\text { Natural logarithm of the geographical distance between } \\
\text { the capital cities of the exporter and importer countries in } \\
\text { kilometers }\end{array}$ & CEPII \\
\hline lang & $\begin{array}{l}\text { Dummy variable that takes the value of } 1 \text { when countries } \\
\text { share an official language and } 0 \text { otherwise }\end{array}$ & CEPII \\
\hline border & $\begin{array}{l}\text { Dummy variable that takes the value of } 1 \text { when countries } \\
\text { share a border and } 0 \text { otherwise }\end{array}$ & CEPII \\
\hline comcol & $\begin{array}{l}\text { Dummy variable that takes the value of } 1 \text { when countries } \\
\text { have or had a colonial relationship and } 0 \text { otherwise }\end{array}$ & CEPII \\
\hline larea_exp & $\begin{array}{l}\text { Natural logarithm of the exporter country's area in square } \\
\text { kilometers }\end{array}$ & CEPII \\
\hline larea_imp & $\begin{array}{l}\text { Natural logarithm of the importer country's area in square } \\
\text { kilometers }\end{array}$ & CEPII \\
\hline landl_exp & $\begin{array}{l}\text { Dummy variable that takes the value of } 1 \text { when the } \\
\text { exporter country is landlocked and } 0 \text { otherwise }\end{array}$ & CEPII \\
\hline landl_imp & $\begin{array}{l}\text { Dummy variable that takes the value of } 1 \text { when the } \\
\text { importer country is landlocked and } 0 \text { otherwise }\end{array}$ & \\
\hline wto_o & $\begin{array}{l}\text { Dummy variable that takes the value of } 1 \text { when the } \\
\text { exporter country is a member of the WTO and } 0 \text { otherwise }\end{array}$ & WTO \\
\hline wto_d & $\begin{array}{l}\text { Dummy variable that takes the value of } 1 \text { when the } \\
\text { importer country is a member of the WTO and } 0 \text { otherwise }\end{array}$ & WTO \\
\hline wto & $\begin{array}{l}\text { Dummy variable that takes the value of } 1 \text { when the } \\
\text { importer and exporter countries are members of the WTO } \\
\text { and } 0 \text { otherwise }\end{array}$ & WTO \\
\hline comcurr & $\begin{array}{l}\text { Dummy variable that takes the value of } 1 \text { when the } \\
\text { exporter and importer countries share a currency and } 0 \\
\text { otherwise }\end{array}$ & $\begin{array}{l}\text { De Sousa (2012) and } \\
\text { the authors }\end{array}$ \\
\hline rta & $\begin{array}{l}\text { Dummy variable that takes the value of } 1 \text { when the } \\
\text { importer and exporter countries are members of the same } \\
\text { free trade area and } 0 \text { otherwise }\end{array}$ & $\begin{array}{l}\text { De Sousa (2012) and } \\
\text { the authors }\end{array}$ \\
\hline sw_o & $\begin{array}{l}\text { Dummy variable that takes the value of } 1 \text { when the } \\
\text { exporter country has an operational SW and } 0 \text { otherwise }\end{array}$ & $\begin{array}{l}\text { IFC-Doing Business } \\
\text { Database and the } \\
\text { authors }\end{array}$ \\
\hline sw_d & $\begin{array}{l}\text { Dummy variable that takes the value of } 1 \text { when the } \\
\text { importer country has an operational SW and } 0 \text { otherwise }\end{array}$ & $\begin{array}{l}\text { IFC-Doing Business } \\
\text { Database and the } \\
\text { authors }\end{array}$ \\
\hline
\end{tabular}


Table A.4. List of Countries

\begin{tabular}{|c|c|c|c|}
\hline Afghanistan & Czech Rep. & Kuwait & Rwanda \\
\hline Albania & Cote d'Ivoire & Kyrgyzstan & Samoa \\
\hline Algeria & People's Rep. of Korea & Lao People's Dem. Rep. & Sao Tome and Principe \\
\hline Angola & Denmark & Latvia & Saudi Arabia \\
\hline Antigua and Barbuda & Djibouti & Lebanon & Senegal \\
\hline Argentina & Dominica & Lesotho & Seychelles \\
\hline Armenia & Dominican Rep. & Liberia & Sierra Leone \\
\hline Australia & Ecuador & Libya & Singapore \\
\hline Austria & Egypt & Lithuania & Slovakia \\
\hline Azerbaijan & El Salvador & Luxembourg & Slovenia \\
\hline Bahamas & Equatorial Guinea & Madagascar & Solomon Isds \\
\hline Bahrain & Eritrea & Malawi & Somalia \\
\hline Bangladesh & Estonia & Malaysia & South Africa \\
\hline Barbados & Ethiopia & Maldives & Spain \\
\hline Belarus & Fiji & Mali & Sri Lanka \\
\hline Belize & Finland & Malta & Sudan \\
\hline Benin & France & Mauritania & Suriname \\
\hline Bermuda & Gabon & Mauritius & Swaziland \\
\hline Bhutan & Gambia & Mexico & Sweden \\
\hline Bolivia & Georgia & Mongolia & Switzerland \\
\hline Bosnia Herzegovina & Germany & Morocco & Syria \\
\hline Botswana & Ghana & Mozambique & TFYR of Macedonia \\
\hline Brazil & Greece & Myanmar & Tajikistan \\
\hline Brunei Darussalam & Greenland & Namibia & Thailand \\
\hline Bulgaria & Guatemala & Nepal & Togo \\
\hline Burkina Faso & Guinea & Netherlands & Tonga \\
\hline Burundi & Guinea-Bissau & New Zealand & Trinidad and Tobago \\
\hline Cambodia & Guyana & Nicaragua & Tunisia \\
\hline Cameroon & Haiti & Niger & Turkey \\
\hline Canada & Honduras & Nigeria & Turkmenistan \\
\hline Cape Verde & Hungary & Norway & Tuvalu \\
\hline Central African Rep. & Iceland & Oman & USA \\
\hline Chad & Indonesia & Pakistan & Uganda \\
\hline Chile & Iran & Palau & Ukraine \\
\hline China & Iraq & Panama & United Arab Emirates \\
\hline China, Hong Kong SAR & Ireland & Papua New Guinea & United Kingdom \\
\hline China, Macao SAR & Israel & Paraguay & Uruguay \\
\hline Colombia & Italy & Peru & Uzbekistan \\
\hline Comoros & Jamaica & Philippines & Vanuatu \\
\hline Congo & Japan & Poland & Venezuela \\
\hline Costa Rica & Jordan & Portugal & Viet Nam \\
\hline Croatia & Kazakhstan & Qatar & Yemen \\
\hline
\end{tabular}




\begin{tabular}{llll}
\hline Cuba & Kenya & Rep. of Korea & Zambia \\
Cyprus & Kiribati & Rep. of Moldova & Zimbabwe \\
\hline
\end{tabular}

Table A.5. PPML estimations

\begin{tabular}{|c|c|c|c|c|}
\hline Dep. Var: & $\begin{array}{c}(1) \\
X \_ \text {TFE }\end{array}$ & $\begin{array}{c}(2) \\
\text { X_TCFE }\end{array}$ & $\begin{array}{c}\text { (3) } \\
\text { X_BTFE }\end{array}$ & $\begin{array}{c}\text { (4) } \\
\text { X_BCTFE }\end{array}$ \\
\hline \multicolumn{5}{|l|}{ IND. Var: } \\
\hline \multirow[t]{2}{*}{ sw_o } & $0.224 * * *$ & 0.004 & 0.0306 & \\
\hline & $(0.021)$ & $(0.040)$ & $(0.0366)$ & \\
\hline \multirow[t]{2}{*}{ sw_d } & $0.122 * * *$ & 0.029 & 0.046 & \\
\hline & $(0.021)$ & $(0.035)$ & $(0.0291)$ & \\
\hline \multirow[t]{2}{*}{ rta } & $0.333^{* * *}$ & $0.242 * * *$ & $-0.061^{*}$ & 0.006 \\
\hline & $(0.021)$ & $(0.047)$ & $(0.035)$ & $(0.047)$ \\
\hline \multirow[t]{2}{*}{ comcur } & $0.100 * * *$ & $0.161^{* *}$ & $0.073 * *$ & -0.033 \\
\hline & $(0.027)$ & $(0.082)$ & $(0.034)$ & $(0.031)$ \\
\hline \multirow[t]{2}{*}{ wto } & $0.126^{* * *}$ & $0.328 * * *$ & $0.367 * * *$ & -0.011 \\
\hline & $(0.027)$ & $(0.053)$ & $(0.041)$ & $(0.101)$ \\
\hline \multirow[t]{2}{*}{ Igdp_exp } & $0.834 * * *$ & $0.537 * * *$ & & \\
\hline & $(0.006)$ & $(0.038)$ & & \\
\hline \multirow[t]{2}{*}{ Igdp_imp } & $0.853 * * *$ & $0.639 * * *$ & & \\
\hline & $(0.007)$ & $(0.037)$ & & \\
\hline \multirow[t]{2}{*}{ Idist } & $-0.470 * * *$ & $-0.638 * * *$ & & \\
\hline & $(0.011)$ & $(0.028)$ & & \\
\hline \multirow[t]{2}{*}{ lang } & $0.184 * * *$ & $0.138 *$ & & \\
\hline & $(0.030)$ & $(0.074)$ & & \\
\hline \multirow[t]{2}{*}{ border } & $0.553 * * *$ & $0.482 * * *$ & & \\
\hline & $(0.038)$ & $(0.087)$ & & \\
\hline \multirow[t]{2}{*}{ comcol } & $1.220 * * *$ & 0.195 & & \\
\hline & $(0.051)$ & $(0.185)$ & & \\
\hline \multirow[t]{2}{*}{ Constant } & $-27.405^{* * *}$ & $-11.931 * * *$ & & \\
\hline & $(0.305)$ & $(1.360)$ & & \\
\hline Observations & 621,592 & 614,667 & 554,819 & 547,056 \\
\hline \multicolumn{5}{|l|}{ Pseudo R- } \\
\hline squared & 0.889 & 0,938 & & 0.992 \\
\hline Number of id & & & 27,242 & \\
\hline
\end{tabular}

